\title{
Influence of Temperature on Growth and Production of Pectenotoxin-2 by a Monoclonal Culture of Dinophysis caudata
}

\author{
Leila Basti ${ }^{1}$ * , Hajime Uchida ${ }^{2}$, Ryoji Matsushima ${ }^{2}$, Ryuichi Watanabe ${ }^{2}$, Toshiyuki Suzuki ${ }^{2}$, \\ Toshifumi Yamatogi ${ }^{3}$ and Satoshi Nagai ${ }^{2, *}$
}

Received: 5 June 2015; Accepted: 20 November 2015; Published: 3 December 2015

Academic Editor: Cherie Motti

1 Department of Ocean Sciences, Tokyo University of Marine Science and Technology, Minato, Tokyo 108-8477, Japan

2 National research Institute of Fisheries Science, Fisheries Research Agency, Fukuura, Kanazawa, Yokohama, Kanagawa 236-8648, Japan; tsuzuki@affrc.go.jp (H.U.); matsur@affrc.go.jp (R.M.); rwatanabe@affrc.go.jp (R.W.); tsuzuki@affrc.go.jp (T.S.)

3 Nagasaki Prefectural Institute of Fisheries, 1551-4 Taira, Nagasaki, Nagasaki 851-2213, Japan; yamatogi011143@pref.nagasaki.lg.jp (T.Y.)

* Correspondence: lbasti1@kaiyodai.ac.jp (L.B.); snagai@affrc.go.jp (S.N.); Tel.: +81-35-463-0732 (L.B.); +81-45-788-7612 (S.N.); Fax: +81-35-463-0732 (L.B.); +81-45-788-5001 (S.N.)

\begin{abstract}
The effects of temperature on growth and production of Lipophilic Toxins (LT) by a monoclonal culture of Dinophysis caudata was studied. The cell density of D. caudata increased significantly with increasing temperature, and was the highest under 27,30 , and $32.5{ }^{\circ} \mathrm{C}$. Temperature affected the average specific growth rate $(\mu)$ during the exponential growth phase (EG), which increased from $15^{\circ} \mathrm{C}$ to $30^{\circ} \mathrm{C}$, and then decreased at $32.5^{\circ} \mathrm{C}$. Liquid chromatography-tandem mass spectrometry (LC-MS/MS) revealed that this strain of $D$. caudata produced only pectenotoxin- 2 (PTX-2) whose concentration increased significantly with incubation period, except at $32.5^{\circ} \mathrm{C}$. It was significantly different between temperatures $\leqslant 18^{\circ} \mathrm{C}, \geqslant 21^{\circ} \mathrm{C}$, and $32.5^{\circ} \mathrm{C}$. The cellular toxin production (CTP, pg. cell ${ }^{-1}$. day $^{-1}$ ) showed variation with growth phase and temperature, except at $32.5^{\circ} \mathrm{C}$. The average net toxin production $\left(R_{\text {tox }}\right)$ was not affected by temperature. During EG, the average specific toxin production rate $\left(\mu_{t o x}\right)$ increased significantly with increase in temperature, reaching a peak of $0.66 \pm 0.01 \mathrm{day}^{-1}$ at $30^{\circ} \mathrm{C}$, and then decreased. Over the entire growth span, $\mu_{\text {tox }}$ was significantly correlated to $\mu$, and this correlation was most significant at 27 and $30{ }^{\circ} \mathrm{C}$. During EG, $\mu_{t o x}$ was affected by both temperature and growth. This study shows that temperature affects growth and toxin production of this strain of D. caudata during EG. In addition, a positive correlation was found between toxin production and growth.
\end{abstract}

Keywords: Dinophysis caudata; culture; growth; pectenotoxin-2; temperature

\section{Introduction}

The human seafood-borne intoxication known as diarrheic shellfish poisoning (DSP) was first identified in Japan in the 1970s [1]. It is associated with the consumption of bivalve molluscs contaminated with lipophilic, polyether, diarrheic shellfish toxins (DST) produced by marine microalgae. Originally, the DST complex comprised three groups of lipophilic toxins that often co-occur in natural samples of plankton and shellfish, and are detected all together by the conventional mouse bioassay (MBA): the okadaic acid (OA) and its analogues the dinophysistoxins (DTX), the yessotoxins (YTX), and the pectenotoxins (PTX) [2,3]. 
OA and its analogues, especially DTX-1 and DTX-2, are the most important DST toxins and cause inflammation of the intestinal tracts and diarrhea [4]. They are specific inhibitors of serine/threonine protein phosphatases 1 (PP1) and 2A (PP2A), two enzymes involved in the regulation of many cellular processes by modulation of protein phosphorylation/dephosphorylation degree $[5,6]$. In addition, OA and its analogues, including DTX-3, were also shown to have tumor promoting activity [7], and to exhibit several cellular effects both in vitro and in vivo (reviewed in [8]). Several toxicological studies showed that YTX exhibit lower potency for the inhibition of PP2A than OA and its analogues when administered orally $[9,10]$. Although YTX were also found to cause adverse pharmacological effects on cellular calcium regulation and phosphodiesterase coordination [11], they are no longer considered diarrheagenic and were removed from the original DST complex due to the fact that no related human intoxication has been reported to date [12]. Likewise, PTX, which are polyether-lactones, are no longer considered part of the DST complex [12], in spite of showing hepatotoxicity to mice following intraperitonial injection [4,13,14], and cytotoxicity in several mammalian cells [15] with antitumorigenic properties (reviewed in [16]). The PTX analogues, PTX secoacid (PTXSA) are not toxic to mice when administered orally $[14,17,18]$. YTX and its analogues are produced by the microalgae Protoceritium reticulatum [11], Lingulodinium polyedrum [19,20], and Gonyaulax spinifera [21]. $\mathrm{OA}$ and its derivatives are produced by some benthic species of the genus Prorocentrum, but mainly by species of the genus Dinophysis which also produce PTX [22].

The genus Dinophysis regroups over a 100 species of pigmented dinoflagellates, some of which have been shown to be mixotrophic $[23,24]$. Among these species of cosmopolitan, polymorphic, and mostly rare marine protists, typically exhibiting low cell densities of $10-10^{2}$ cells. $\mathrm{L}^{-1}$ and atypically occurring at $10^{4}-10^{5}$ cells. $\mathrm{L}^{-1}$ in coastal waters [22,23,25], 12 have been found to produce OA, DTX, and/or PTX, and seven have been associated with DSP events (D. acuminata, D. acuta, D. caudata, D. fortii, D. miles, D. ovum, and D. sacculus) [26]. Species of Dinophysis form a small fraction of the microplankton community $(1 \%-5 \%)$ and tend to aggregate in patchy thin layers, exceptionally forming red tides of more than $10^{6}$ cells. $\mathrm{L}^{-1}$ [26-33]. Nonetheless, DSP events associated with the toxins of Dinophysis spp. can emerge in any bivalve cultivation area covered by monitoring programs of both the cells and the toxins of Dinophysis [33].

The cellular toxic profile and content of Dinophysis spp. affect the magnitude of contamination of bivalves with LT. However, DSP events often occur in areas where several Dinophysis species with different toxin profiles are reported [26]. For instance, the contributions of blooms of D. caudata, co-occurring with or occurring after blooms of other toxigenic species such as D. acuminata, D. sacculus and D. miles, to the associated DSP events in Southern Europe, Northern Africa, Mexico, the Gulf of Mexico, South America, Southeast Asia, and Australia remain controversial [34-48]. Information on toxin profiles and toxin content of D. caudata, and other species of Dinophysis, is mainly available from cell concentrates and/or picked cells, due to difficulties to establish and maintain cultures of Dinophysis spp. [26,48]. Analyses of picked cells of D. caudata, from different locations, by HPLC-FLD and LC-MS showed the presence of OA and DTX-1 at moderate to high values [49], traces of OA and/or DTX-2 with high levels of PTX-2 [37], or only high levels of PTX-2 [50]. In addition, inter-annual variability in the toxin content of $D$. caudata picked from the same location was also found $[37,50,51]$. Red tides of $D$. caudata with associated fish mortality were reported in the Seto Inland Sea, Japan [52], and caused major DSP contamination in Singapore [53]. In a recent study, a monoclonal culture of $D$. caudata, isolated from western Japan, was found to be highly lethal, under controlled laboratory conditions, to Japanese scallops, Patinopecten yessoensis, and noble scallops, Mimachlamys nobilis, raising further questions regarding the toxicity of Dinophysis [54]. The recent successful cultivation of D. caudata [55] was crucial to understand the physiology and toxicology of this species, and other species that were also successfully cultured, namely D. acuminata [56], D. fortii [57], D. infundibulus [58], D. tripos [59,60], D. acuta [61], D. cf. ovum [62], and D. sacculus [63]. The production and accumulation of toxins in microalgal cells is controlled by several intrinsic and extrinsic factors [64,65], and temperature could be one of them, especially for D. caudata which is 
widely distributed in tropical and temperate neritic waters [33]. The present study considers the effect of seven experimental temperatures, covering the natural range of geographical distribution of D. caudata, on the growth and toxin production of a strain isolated from western Japan and maintained in a monoclonal culture.

\section{Results and Discussion}

\subsection{Growth under Different Temperatures}

Cell densities of Dinophysis caudata increased significantly (Kruskal Wallis ANOVA, $p<0.05$ ) under all experimental temperatures (Figure 1), reaching the highest final yield at $32.5{ }^{\circ} \mathrm{C}$. Cell densities of Mesodinium rubrum, on the other hand, decreased rapidly with incubation time and increasing temperature, in a trend much similar to previous observations for similar temperatures [55], i.e., its exponential decline occurred more rapidly at temperatures $>27^{\circ} \mathrm{C}$. Maximal yield in D. caudata cultures was significantly higher at temperatures above $21^{\circ} \mathrm{C}$ (Table 1 ).

a

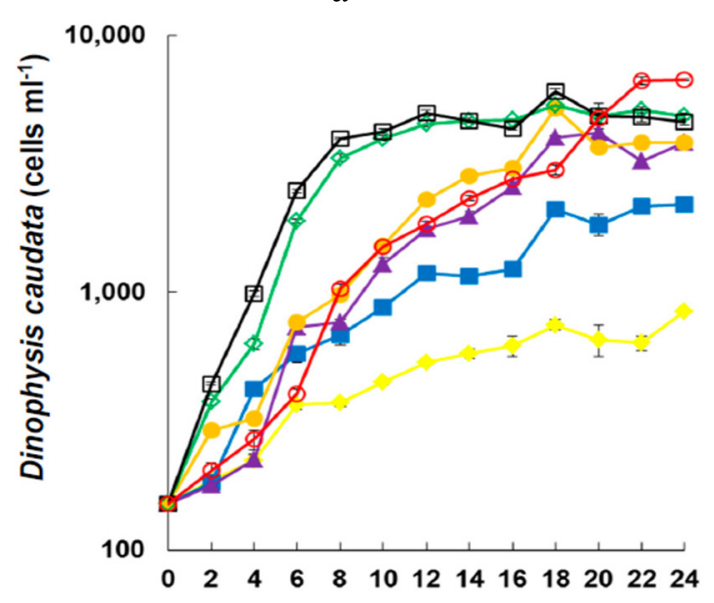

b

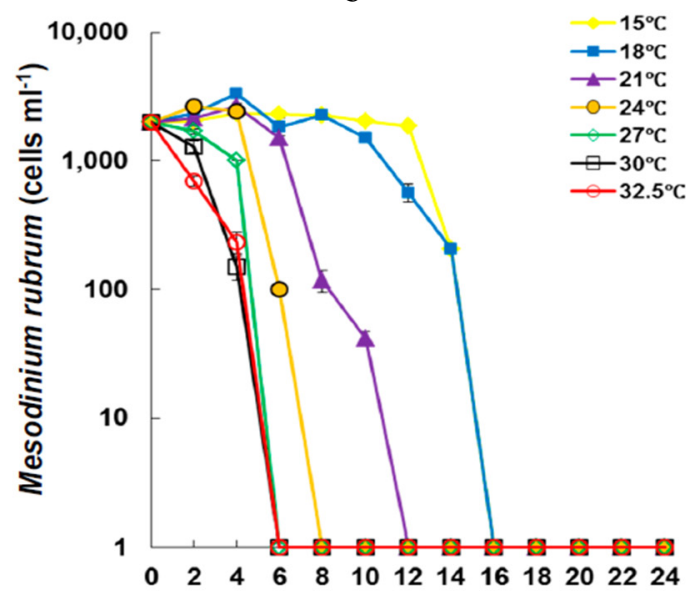

Time (davs)

Figure 1. Changes in cell density of Dinophysis caudata (a), fed with Mesodinium rubrum (b), grown under different temperatures. Vertical bars denote the standard deviation (SD) of the mean $(n=3)$.

Table 1. Results of the multiple comparisons test $H$ (Kruskal Wallis Anova) for the effects of temperature $\left({ }^{\circ} \mathrm{C}\right)$ on cell density of Dinophysis caudate.

\begin{tabular}{cccccccc}
\hline \multicolumn{7}{c}{ Temperature $\left({ }^{\circ} \mathrm{C}\right)$} \\
\hline & $\mathbf{1 5}$ & $\mathbf{1 8}$ & $\mathbf{2 1}$ & $\mathbf{2 4}$ & $\mathbf{2 7}$ & $\mathbf{3 0}$ & $\mathbf{3 2 . 5}$ \\
\hline 15 & & & & & & & \\
18 & NS & & & & & & \\
21 & $*$ & NS & & & & & \\
24 & $* * *$ & NS & NS & & & & \\
27 & $* * *$ & $* * *$ & $*$ & NS & & & \\
30 & $* * *$ & $* * *$ & $*$ & NS & NS & & \\
32.5 & $* * *$ & NS & NS & NS & NS & NS & \\
\hline \multicolumn{7}{c}{ NS: Non-significant, ${ }^{*} p<0.05 ;{ }^{* *} p<0.001}$.
\end{tabular}

During exponential growth phase (EG), the specific growth rate $(\mu)$ of $D$. caudata showed significant difference in response to different temperatures (Figure 2). It ranged from $0.21 \pm 0.01$ day $^{-1}$ at $15{ }^{\circ} \mathrm{C}$ to $0.67 \pm 0.00$ day $^{-1}$ at $30{ }^{\circ} \mathrm{C}$; increasing significantly from $15{ }^{\circ} \mathrm{C}$ to 
$30{ }^{\circ} \mathrm{C}$, and then decreasing at $32.5^{\circ} \mathrm{C}$. The specific growth rate of $D$. caudata was within the range of specific growth rates reported in previous studies for the same species isolated from Japan, and other Dinophysis species (D. acuminata, D. acuta, D. fortii, D. infundibulus, D. norvegica, D. tripos, and D. sacculus), from both in situ and culture estimates (reviewed in [66]). It was optimal under 24, 27, and $30{ }^{\circ} \mathrm{C}$, which reflects the natural distribution of D. caudata in tropical and warm sub-tropical areas, with higher cell density, and exceptional blooms, occurring in warmer tropical areas [33]. Temperatures lower than $21^{\circ} \mathrm{C}$ and above $30^{\circ} \mathrm{C}$ seem to be outside the lower and higher boundaries of optimal growth of D. caudata, although insufficient acclimation at the lowest and the highest temperatures should not be excluded. In a previous study, increasing temperature was shown to enhance maximal yield and specific growth of $D$. acuminata in culture experiments, also reflecting its cosmopolitan geographical distribution $[67,68]$.

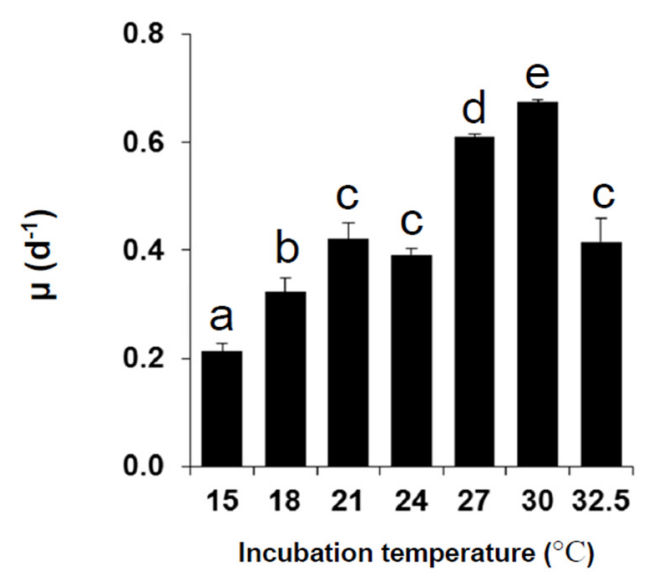

Figure 2. Average specific growth rates of Dinophysis caudata during the exponential growth phase under different experimental temperatures. Vertical bars denote the standard deviation (SD) of the mean $(n=3)$. Different letters indicate significant differences among treatments (ANOVA, Neuwman-Keuls, $p<0.05)$.

Temperature affects the physiology, notably the metabolic activity of phytoplankton, which results in increased food uptake and active cell division [69]. Temperature does also affect the feeding behavior of Dinophysis spp., and the swimming behavior and speed of both prey and predator resulting in higher growth rates with increasing temperature [65,70]. The densities of the prey M. rubrum decreased rapidly at temperatures $>21^{\circ} \mathrm{C}$, especially at temperatures exceeding $27^{\circ} \mathrm{C}$ under which the rapid decrease occurred within less than six days, coincident with EG of D. caudata. The difference in growth rates during EG should have been linked to active grazing sustaining the mixotrophic growth of Dinophysis through both photosynthesis, and essential nutrients and growth factors obtained via prey consumption [71-79]. The swimming speed of the prey M. rubrum decreases with decreasing temperature [75]. Therefore, the lower growth rates at lower temperatures in spite of the longer availability of the prey should have been related to the direct influence of temperature on the physiology of D. caudata and thus its growth. It should also be noted that growth rates are influenced by both extrinsic and intrinsic factors, including the experimental conditions but also genetic variability inherent to the strain of Dinophysis and to the prey itself [55].

\subsection{Toxin Content and Production under Different Temperatures}

The strain of $D$. caudata used in this study produced only PTX-2 (Figure 3). The concentration of PTX-2 in the culture was affected by both incubation period (Mann-Whitney $\mathrm{U}$ test, $p<0.05$ ) and temperature (Kruskal Wallis ANOVA, $p<0.05$ ).

There was a significant increase in the toxin content of the culture with increased incubation time (Mann-Whiney U Test, $p<0.05$ ) associated with increased cell density of $D$. caudata. Within 22-24 days 
of incubation, the concentration of PTX-2 reached the highest value of $2.45 \pm 0.25 \times 10^{3} \mathrm{ng} \cdot \mathrm{mL}^{-1}$ at $30^{\circ} \mathrm{C}$. The lowest concentration of PTX-2 $\left(0.45 \pm 0.05 \times 10^{3} \mathrm{ng} \cdot \mathrm{mL}^{-1}\right)$ throughout the experimental period was registered for incubation at $32.5^{\circ} \mathrm{C}$, a temperature under which PTX-2 concentration decreased. The concentration of PTX-2 in the culture was significantly different under temperatures $\leqslant 18^{\circ} \mathrm{C}$ and $\geqslant 21^{\circ} \mathrm{C}$, but not significantly different under $21,24,27$, and $30^{\circ} \mathrm{C}$. On the other hand, the concentration of PTX-2 in the culture was significantly different under $32.5^{\circ} \mathrm{C}$, and 24,27 and $30{ }^{\circ} \mathrm{C}$ (Table 2). The PTX-2 cellular toxin production of D. caudata, which corresponds to the total toxin production (particulate plus dissolved) per cell per $\mathrm{mL}$ of culture, showed variation with growth phase and temperature (Figure 3). Except for the decreased cellular toxin production for incubation at $32.5^{\circ} \mathrm{C}$, from $188.45 \pm 5.16 \mathrm{pg}$. cell ${ }^{-1}$ to $39.84 \pm 7.84 \mathrm{pg}$. cell ${ }^{-1}$, there was a decrease at the beginning of the incubation period until day 6 , corresponding to early to mid-exponential growth, a stabilization between 6 and 18 days, corresponding to late-exponential to mid-stationary growth, and then an increase between 18 and 24 days, corresponding to late stationary growth, to levels higher than the ones registered during the first six days.
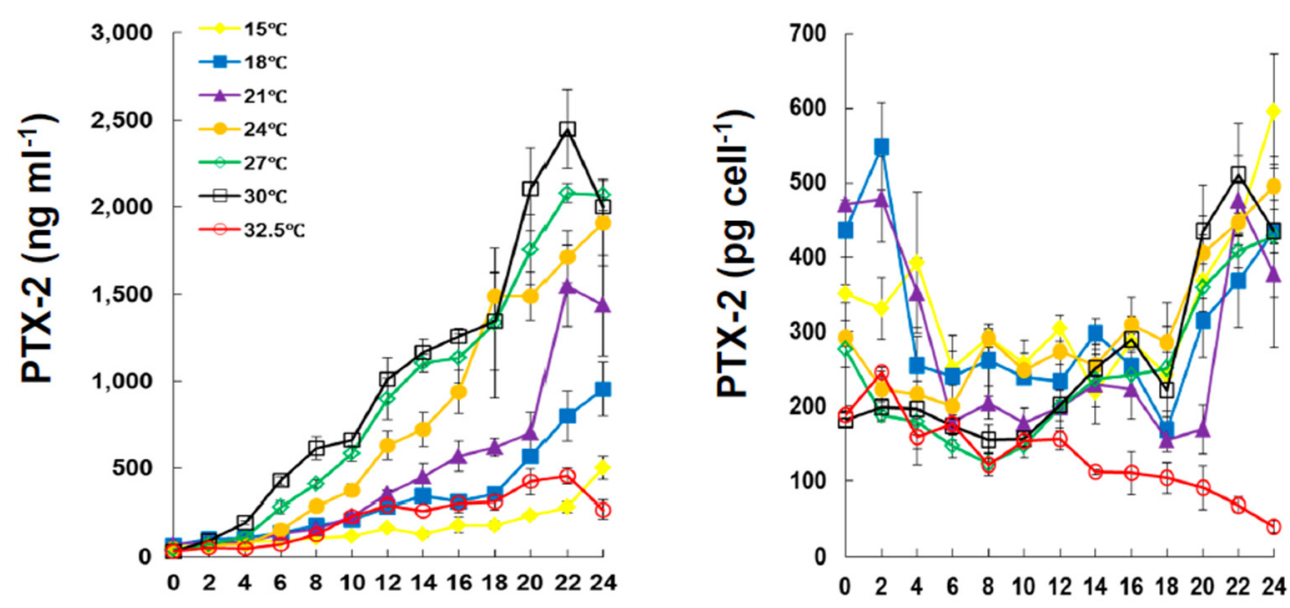

\section{Time (days)}

Figure 3. Concentration of PTX-2 (ng. mL ${ }^{-1}$ ) and cellular production (particulate plus dissolved) of PTX-2 (pg. cell ${ }^{-1}$ ) in cultures of Dinophysis caudata grown at different temperatures. Vertical bars denote the standard deviation (SD) of the mean $(n=3)$. PTX $=$ pectenotoxins.

Table 2. Results of the multiple comparisons test $H$ (Kruskal Wallis ANOVA) for the effects of temperature $\left({ }^{\circ} \mathrm{C}\right)$ on PTX-2 concentration of Dinophysis caudate.

\begin{tabular}{cccccccc}
\hline \multicolumn{7}{c}{ Temperature $\left({ }^{\circ} \mathrm{C}\right)$} \\
\hline & $\mathbf{1 5}$ & $\mathbf{1 8}$ & $\mathbf{2 1}$ & $\mathbf{2 4}$ & $\mathbf{2 7}$ & $\mathbf{3 0}$ & $\mathbf{3 2 . 5}$ \\
\hline 15 & & & & & & & \\
18 & NS & & & & & & \\
21 & $*$ & NS & & & & & \\
24 & $* * *$ & NS & NS & & & & \\
27 & $* * *$ & NS & NS & NS & & & \\
30 & $* * *$ & $*$ & NS & NS & NS & & \\
32.5 & NS & NS & NS & $*$ & $*$ & $*$ & \\
NS: Non-significant, ${ }^{*} p<0.05 ; * *$ & $p<0.001$. PTX = pectenotoxins.
\end{tabular}

The average net toxin production $\left(\mathrm{R}_{\mathrm{tox}}\right)$ of $D$. caudata (Figure 4) ranged from $35.16 \pm 12.87 \mathrm{pg} \cdot \mathrm{cell}^{-1} \cdot \mathrm{day}^{-1}$ at $15{ }^{\circ} \mathrm{C}$ to $16.29 \pm 7.24 \mathrm{pg} \cdot \mathrm{cell}^{-1} \cdot \mathrm{day}^{-1}$ at $32.5^{\circ} \mathrm{C}$ (Table 3). The $\mathrm{R}_{\text {tox }}$ was significantly affected by the incubation period (Kruskal Wallis ANOVA, $p<0.001$ ) but 
not by temperature. Except for the peak at $15^{\circ} \mathrm{C}$ from day $16-24$, the $\mathrm{R}_{\text {tox }}$ decreased with incubation period. The increase in the concentration of PTX-2 in the culture medium with incubation period and the variation of $R_{\text {tox }}$ of PTX-2 with growth phase and temperature were, therefore, most probably related to differential release of PTX-2 into the culture medium than to an actual differential cellular production of PTX-2 with growth phase and temperature. The cellular toxin content (CTC) of PTX-2 and DTX-1 of D. acuminata in culture were also found to be unaffected by experimental temperature whereas the CTC of OA increased significantly with increasing temperature [67].

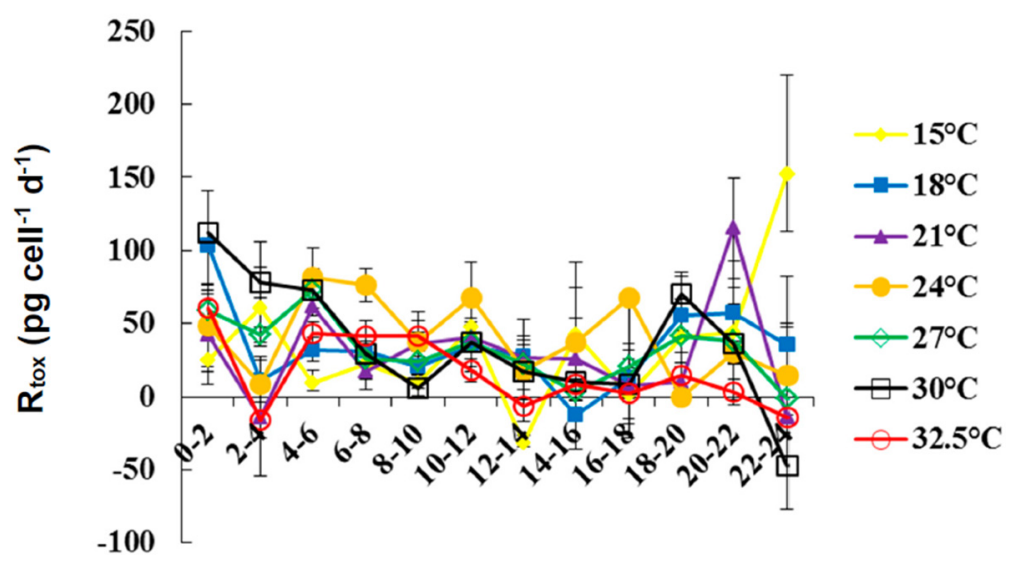

Time (days)

Figure 4. Net toxin production $\left(\mathrm{R}_{\mathrm{tox}}\right)$ of PTX2 by Dinophysis caudata grown at different temperatures. Vertical bars denote the standard deviation $(\mathrm{SD})$ of the mean $(n=3)$.

Table 3. Net toxin production $\left(\mathrm{R}_{\mathrm{tox}}, \mathrm{pg} \cdot \mathrm{cell}^{-1} \cdot \mathrm{day}^{-1}\right)$ of Dinophysis caudata during the entire experimental growth under different temperatures.

\begin{tabular}{ccccccccc}
\hline & & \multicolumn{7}{c}{ Temperature $\left({ }^{\circ} \mathbf{C}\right)$} \\
\cline { 3 - 9 } & & $\mathbf{1 5}$ & $\mathbf{1 8}$ & $\mathbf{2 1}$ & $\mathbf{2 4}$ & $\mathbf{2 7}$ & $\mathbf{3 0}$ & $\mathbf{3 2 . 5}$ \\
\hline \multirow{4}{*}{$\mathrm{R}_{\text {tox }}$} & Min & -31.67 & -12.31 & -14.77 & 0 & -1.35 & -47.60 & -16.04 \\
& Max & 152.04 & 103.32 & 115.33 & 81.39 & 72.86 & 112.30 & 60.65 \\
& Mean & 35.16 & 33.98 & 29.46 & 22.93 & 32.06 & 35.79 & 16.29 \\
& SE & 12.87 & 8.35 & 101.63 & 8.01 & 6.10 & 12.27 & 7.24 \\
\hline
\end{tabular}

In another report, the intracellular amount of PTX-2 of D. acuminata and D. fortii were found to be equal to the total amount of PTX-2 in culture experiments, whereas the intracellular amount of OA and DTX-1 were different [66]. It seems that the production, retention/release of toxin, at least PTX-2, varies among species of Dinophysis and/or strains of the same species.

Early HPLC-FLD analyses, that did not search for PTX, showed very low CTC of OA $\left(0.07-0.14 \mathrm{pg} \cdot\right.$ cell $\left.^{-1}\right)$ in D. caudata from Singapore $[53,80]$, and moderate to high CTC of OA (7.9-56.5 pg. cell ${ }^{-1}$ ) and DTX1 (7.2-53.9 pg. cell $\left.{ }^{-1}\right)$ from the Philippines [49]. Recent LC-MS analyses, however, showed that PTX-2 is the dominant or the only toxin present in Northwest Spain with CTC ranging from 50 to $120 \mathrm{pg}$. cell ${ }^{-1}$ accompanied by traces of OA and/or DTX-2 [42,50]. Differential variations of CTC of OA, DTX-1, and PTX-2 with growth phase were reported for cultured D. acuminata from northeastern USA, with a significant decrease of PTX-2 as the culture aged [68]. On the other hand, the average specific toxin production rate $\left(\mu_{\text {tox }}\right)$ during exponential growth phase showed significant difference among temperature (Figure 5). While $\mu_{\text {tox }}$ was not significantly different at the lower temperatures, 15 to $21^{\circ} \mathrm{C}$, it increased significantly from $24^{\circ} \mathrm{C}$, reaching a peak of $0.66 \pm 0.01$ day $^{-1}$ at $30^{\circ} \mathrm{C}$, and then decreased at $32.5^{\circ} \mathrm{C}$. 


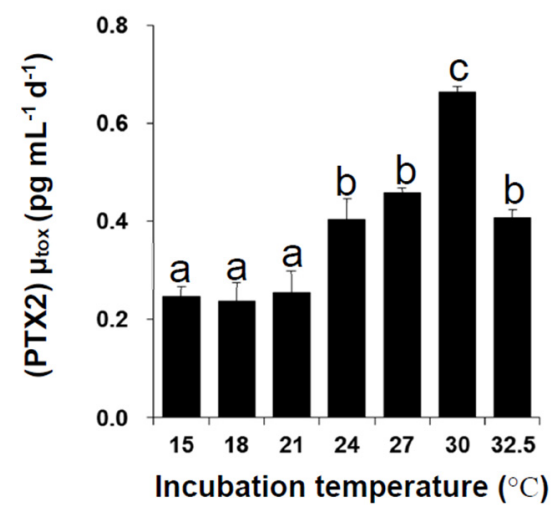

Figure 5. Average specific toxin production rate $\left(\mu_{\mathrm{tox}}\right)$ of PTX-2 by Dinophysis caudata during the exponential growth phase, cultured under different temperatures. Vertical bars denote the standard deviation $(\mathrm{SD})$ of the mean $(n=3)$.

These results suggest that, during early exponential growth, temperature is a direct contributor to the production of PTX-2, but that PTX-2 production is also related to growth. Indeed, $\mu_{\text {tox }}$ was significantly correlated to $\mu$ in cultures of D. caudata during EG (Figure 6) but also over the entire incubation period, all temperatures considered $(r=0.50, p<0.001)$. But this correlation was most significantly contributed from the $\mu_{\text {tox }}$ at $27{ }^{\circ} \mathrm{C}(r=0.80, p<0.01)$ and $30{ }^{\circ} \mathrm{C}(r=0.82, p<0.01)$. In a previous study, temperature was found to affect PTX-2 production of a strain of D. acuminata from Japan [65], whereas another report showed that both temperature and light did not affect the production of PTX-2 of another strain of D. acuminata form USA [68]. Several factors may interactively influence the production of PTX-2 in D. caudata, including the prey organism, growth, and temperature. In the light of these results, further studies should be considered to understand the factors that influence toxin production in cultures of D. caudata.

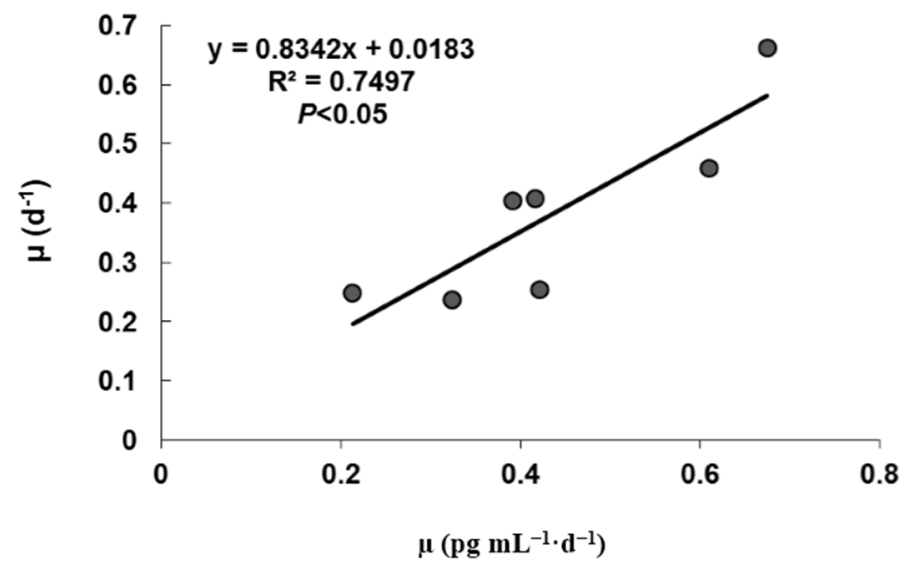

Figure 6. Relationship between specific toxin production rate $\left(\mu_{\text {tox }}\right)$ and specific growth rate $(\mu)$ of Dinophysis caudata during the exponential growth phase. Averaged values were plotted.

\section{Experimental Section}

\subsection{Isolation and Maintenance of Clonal Strains}

The cryptophyte Teleaulax amphioxeia and the marine ciliate Mesodinium rubrum were isolated from Inokushi Bay, Oita Prefecture, Japan $\left(32^{\circ} 47^{\prime} \mathrm{N}, 131^{\circ} 53^{\prime} \mathrm{E}\right)$, in 2007 [55,57]. Cultures of M. rubrum were maintained at $18^{\circ} \mathrm{C}$, by weekly re-inoculations of $50 \mathrm{~mL}$ of the culture into a $100 \mathrm{~mL}$ of modified $\mathrm{f} / 2$ medium [81-83], with the addition of $50 \mu \mathrm{L}$ of T. amphioxeia culture as prey, under an irradiance 
of $100-150 \mu \mathrm{mol}$ photons $\mathrm{m}^{-2} \cdot \mathrm{s}^{-1}$ provided from cool white fluorescent lamps with a $12 \mathrm{~h}$ light: $12 \mathrm{~h}$ dark cycle. The culture medium was prepared with $1 / 3$ nitrate, phosphate, and metals and $1 / 10$ vitamins based on the enrichment of natural seawater collected from Hiroshima Bay (salinity adjusted to 30). Cultures of T. amphioxeia were maintained under the same conditions as those of $M$. rubrum, by re-inoculating $0.3 \mathrm{~mL}$ of the culture into $150 \mathrm{~mL}$ of the modified $\mathrm{f} / 2$ medium. Cultures of Dinophysis caudata were established from single cells of $D$. caudata isolated from a seawater sample collected from Nagasaki Prefecture. The cells did not have 2 tailing flagella (planozygotes), hence the established cultures, from a 1 -cell, were monoclonal. Cultures of $D$. caudata were initiated by incubating individual cells in a 12-well microplate in the culture medium with M. rubrum. Cultures were maintained by incubation in $10 \mathrm{~mL}$ culture tubes under each experimental temperature, for 20 days. The volume of the cultures was gradually increased to $150 \mathrm{~mL}$ through monthly re-inoculations into M. rubrum cultures at $21-23^{\circ} \mathrm{C}$ in a $250 \mathrm{~mL}$ carbonate Erlenmeyer flask [55].

\subsection{Growth Experiments}

The effects of temperature on toxin production were investigated at seven temperatures $(15,18$, $21,24,27,30$, and $32.5^{\circ} \mathrm{C}$ ), under the same conditions specified for culture maintenance, except for temperature. Both M. rubrum and D. caudata cultures were pre-conditioned to each experimental temperature prior to growth and toxin measurements for 20 days. The M. rubrum cultures grown at each temperature were collected at the late exponential growth phase $\left(\mathrm{ca} .8 .5 \times 10^{3}\right.$ cells $\left.\mathrm{mL}^{-1}\right)$, and then diluted with the culture medium to an initial concentration of $c a .2 \times 10^{3}$ cells. $\mathrm{mL}^{-1}$. Cultures of $D$. caudata for each temperature were added to the matching culture of $M$. rubrum for a final concentration of 150 cell. $\mathrm{mL}^{-1}$ of $D$. caudata. Every 2 days, the cultures were shaken and samples collected for cell counts $(0.5 \mathrm{~mL}$, in triplicate), and DSP and lipophilic toxin analysis $(1.0 \mathrm{~mL}$, in triplicate). Cells of $M$. rubrum and D. caudata were counted using an inverted microscope. Samples for toxin analysis were kept at $-20^{\circ} \mathrm{C}$.

The specific growth rate $\left(\mu\right.$, day $\left.^{-1}\right)$ of $D$. caudata was calculated from the exponential growth phase (EG), between sampling intervals ( $t, 2$ days), as follows [84]:

$$
\mu=\frac{\ln \left(N_{2} / N_{1}\right)}{t}
$$

where, $N_{1}$ and $N_{2}$ are the cell densities of $D$. caudata at time 1 and time 2, respectively. $t$ is the experimental time (days), and $\mu$ is the specific growth rate $\left(\right.$ day $\left.^{-1}\right)$. The mean specific growth rates of $D$. caudata were determined from the slope of the linear regression of the natural logarithm of cell density versus incubation time during the exponential growth phase.

\subsection{Toxin Analyses}

The solid phase extraction (SPE) procedure was used for toxin analysis [65,85]. Following a 2 min sonication, each sample was loaded on a Sep-Pak C18 cartridge column (Waters, Milford, MA, USA), previously preconditioned with methanol $(5 \mathrm{~mL})$ and distilled water $(10 \mathrm{~mL})$. Sea salt was then removed by washing the cartridge with $5 \mathrm{~mL}$ distilled water, and the toxins were eluted with $5 \mathrm{~mL}$ methanol. Following evaporation, the residue was dissolved in $200 \mu \mathrm{L}$ methanol, and an aliquot of the solution was directly analyzed by liquid chromatography-tandem mass spectrometry (LC-MS/MS) analysis.

The LC-MS/MS analysis was carried out according to a previous method with slight modifications [86]. The lowest detection limits for OA, DTX1, and PTX2 were 0.6, 0.6, and $1.6 \mathrm{ng} \cdot \mathrm{mL}^{-1}$, respectively. These levels are equivalent to $1.2 \mathrm{pg} \cdot \mathrm{cell}^{-1}$ of OA/DTX1 and $3.2 \mathrm{pg} \cdot \mathrm{cell}^{-1}$ of PTX2, when 100 cells of the toxic plankton were analyzed using our LC-MS/MS method. 
The specific toxin production rate $\left(\mu_{\mathrm{tox}}, \mathrm{pg} \cdot \mathrm{mL}^{-1} \cdot \mathrm{day}^{-1}\right)$ was calculated based on Equation (1), by substituting $N$, the cell density, by $T$, the toxin concentration, between two consecutive sampling points, during EG phase, as follows:

$$
\mu_{\text {tox }}=\frac{\ln \left(N_{2} T_{2} / N_{1} T_{1}\right)}{t}
$$

To account for cell growth rates on toxin production, the net toxin production rate $\left(\mathrm{R}_{\text {tox }}\right.$; $\mathrm{pg} \cdot \mathrm{cell}^{-1} \cdot \mathrm{day}^{-1}$ ) was determined from the following equation $[81,87]$ :

$$
\mathrm{R}_{\mathrm{tox}}=\frac{\left(T_{2}-T_{1}\right)}{N_{m} \times t}, N_{m}=\frac{\left(N_{2}-N_{1}\right)}{\ln \left(N_{2} / N_{1}\right)}
$$

where, $T_{1}$ and $T_{2}$ are the toxin concentrations and $N_{1}$ and $N_{2}$ are the cell densities of D. caudata both at the first and subsequent sampling time, respectively, and $N_{m}$ is the geometric mean density of D. caudata during the sampling period.

\subsection{Data Analysis}

Normality (Shapiro-Wilk) and homoscedasticity (Cochran test and Bartlett test) were checked $a$ priori. When the assumptions of the normal distribution were met, multivariate or factorial ANOVA were used to test the effects of incubation period and temperature followed by the post-hoc test, Fisher's Least Significant Difference (LSD). Otherwise, the non-parametric Kruskal-Wallis ANOVA was considered, followed by the multiple comparisons $\mathrm{H}$ test to assess the level at which the significant effects occurred. The effects of incubation period and temperature on toxin concentration and net toxin production were tested with Spearman rank order correlations followed by the Mann-Whitney $U$ test. Differences between replications, for all data sets, were not significant. Three levels of significance were considered, $\alpha=0.05,0.01$, and 0.001 .

\section{Conclusions}

In conclusion, cell densities of $D$. caudata increased significantly with increasing temperature, with the highest yields observed under 27,30 , and $32.5^{\circ} \mathrm{C}$. It is interesting that $D$. caudata only produced PTX-2. Because PTX-2 is rapidly converted to non-toxic PTX-2 seco acid in many bivalve species, except for Japanese scallops Patinopecten yessoensis $[85,86,88]$, appearance of $D$. caudata even at high densities could not be problematic for many bivalve species in terms of shellfish toxin regulation by both mouth bioassay and LC-MS/MS. On the other hand, PTX-2 still has attracted attention for toxicological and pharmacological reasons. Therefore, results obtained in the present study would be very useful for optimization of mass production of PTX-2 through large scale cultures of $D$. caudata.

Acknowledgments: This work was supported by a Grant-In-Aid for Scientific Research from the Japan Society for the Promotion of Science (No. 25.03517), Regulatory Research Projects for food safety, animal and plant protection, and Cross-ministerial Strategic Innovation Promotion Program.

Author Contributions: Satoshi Nagai conceived, designed, and conducted the growth experiments; Toshiyuki Suzuki acquired the funds; Hajime Uchida analyzed the toxin samples; Leila Basti analyzed the data; Ryoji Matsushima and Ryuichi Watanabe provided the reagents/materials/analysis tools; Toshifumi Yamatogi sampled Dinophysis; Leila Basti wrote the paper.

Conflicts of Interest: The authors declare no conflict of interest.

\section{References}

1. Yasumoto, T.; Oshima, Y.; Yamaguchi, M. Occurrence of a new type of shellfish poisoning in the Tohoku district. Bull. Jpn. Soc. Sci. Fish. 1978, 44, 1249-1255.

2. Yasumoto, T.; Murata, M. Marine toxins. Chem. Rev. 1993, 93, 1897-1993.

3. Yasumoto, T.; Murata, M.; Oshima, Y.; Sano, M.; Matsumoto, G.; Clardy, J. Diarrhetic shellfish toxins. Tetrahedron 1985, 41, 1019-1025. [CrossRef] 
4. Terao, K.; Ito, E.; Yanagi, T.; Yasumoto, T. Histopatholgical studies on marine toxin poisoning. 1. Ultrastructural changes in the small intestine and liver of suckling mice induced by dinophysistoxin-1 and pectenotoxin-1. Toxicon 1986, 24, 1141-1151. [CrossRef]

5. Bialojan, C.; Takai, A. Inhibitory effect of a marine-sponge toxin, okadaic acid, on protein phosphatases. Biochem. J. 1998, 256, 283-290.

6. Fernández, J.J.; Candenas, M.L.; Souto, M.L.; Trujillo, M.M.; Norte, M. Okadaic acid, useful tool for studying cellular processes. Curr. Med. Chem. 2002, 9, 229-262. [CrossRef] [PubMed]

7. Fujiki, H.; Suganuma, M.; Suguri, H.; Yoshizawa, S.; Takagi, K.; Uda, N.; Wakamatsu, K.; Yamada, K.; Murata, M.; Yasumoto, T.; et al. Diarrhetic shellfish toxin, dinophysistoxin-1, is a potent tumor promoter on mouse skin. Jpn. J. Cancer Res. 1988, 79, 1089-1093. [CrossRef] [PubMed]

8. Tubaro, A.; Sosa, S.; Bornancin, A.; Hungerford, J. Pharmacology and toxicology of diarrheic shellfish toxins. In Seafood and Freshwater Toxins. Pharmacology, Physiology and Detection, 2nd ed.; Botana, L.M., Ed.; CRC Press: Boca Raton, FL, USA, 2008; pp. 229-253.

9. Ogino, H.; Kumagai, M.; Yasumoto, T. Toxicologic evaluation of yessotoxin. Nat. Toxins 1997, 5, $255-259$. [CrossRef]

10. Terao, K.; Ito, E.; Orada, M.; Murata, M.; Yasumoto, T. Histopathological studies on experimental marine toxin poisoning-5. The effects in mice of yessotoxin isolated from Patinopecten yessoensis and of a desulfated derivative. Toxicon 1990, 28, 1095-1104. [CrossRef]

11. Satake, M.; Ichimura, T.; Sekiguchi, K.; Yoshimatsu, S.; Oshima, Y. Confirmation of yessotoxin and 45,46,47-trinoryessotoxin production by Protoceratium reticulatum collected in Japan. Nat. Toxins 1999, 7 , 147-150. [CrossRef]

12. Lawrence, J.; Loreal, H.; Toyofuku, H.; Hess, P.; Iddya, K.; Ababouch, L. Assessment and Management of Biotoxin Risks in Bivalve Molluscs; FAO Fisheries and Aquaculture Technical Paper 551; FAO: Rome, Italy, 2011; p. 337.

13. Yoon, M.Y.; Kim, Y.Z. Acute toxicity of pectenotoxin 2 and its effects on hepatic metabolizing enzyme in mice. Korean J. Toxicol. 1997, 13, 183-186.

14. Ito, E.; Suzuki, T.; Oshima, Y.; Yasumoto, T. Studies on diarrheic activity on pectenotoxin-6 in the mouse and rat. Toxicon 2008, 15, 707-716. [CrossRef] [PubMed]

15. Jun, J.H.; Sim, C.S.; Lee, C.O. Cytotoxic compounds from a two-sponge association. J. Nat. Prod. 1995, 58, 1722-1726.

16. Vilariño, N.; Espiña, B. Pharmacology of pectenotoxins. In Seafood and Freshwater Toxins. Pharmacology, Physiology and Detection, 2nd ed.; Botana, L.M., Ed.; CRC Press: Boca Raton, FL, USA, 2008; pp. 361-369.

17. Miles, C.O.; Wilkins, A.L.; Munday, R.; Dines, M.H.; Hawkes, A.D.; Briggs, L.R.; Quilliam, M.A.; MacKenzie, A.L.; Beuzenberg, V.; Towers, N.R. Isolation of pectenotpxin-2 from Dinophysis acuta and its conversion to pectenotoxin-2 seco acid, and preliminary assessment of their acute toxicities. Toxicon 2004, 43, 1-9. [CrossRef] [PubMed]

18. Miles, C.O.; Wilkins, A.L.; Munday, J.S.; Munday, R.; Hawkes, A.D.; Jensen, D.J.; Cooney, J.M.; Beuzenberg, V. Production of 7-epi-pectenotoxin-2 seco acid and assessment of its acute toxicity to mice. J. Agric. Food Chem. 2006, 54, 1530-1534. [CrossRef] [PubMed]

19. Draisci, R.; Ferretti, E.; Palleschi, L.; Marchiafava, C.; Poletti, R.; Milandri, A.; Ceredi, A.; Popei, M. High levels of yessotoxin in mussels and presence of yessotoxin and homoyessotoxin in dinoflagellates of the Adriatic Sea. Toxicon 1999, 37, 1187-1193. [CrossRef]

20. Paz, B.; Riobó, P.; Fernández, M.L.; Fraga, S.; Franco, J.M. Production and release of yessotoxins by the dinoflagellates Protoceratium reticulatum and Lingulodinium polyedrum in culture. Toxicon 2004, 44, 251-258. [CrossRef] [PubMed]

21. Rhodes, L.; McNabb, P.; de Salas, M.; Briggs, L.; Beuzenberg, V.; Gladstone, M. Yessotoxin production by Gonyaulax spinifera. Harmful Algae 2006, 5, 148-155. [CrossRef]

22. Camacho, F.G.; Rodríguez, J.G.; Miron, S.S.; Ceron García, M.C.; Belarbi, E.H.; Christi, Y.; Molima Grima, E. Biotechnological significance of toxic marine dinoflagellates. Biotechnol. Adv. 2007, 25, 176-194. [CrossRef] [PubMed]

23. Gómez, F. A list of free-living dinoflagellate species in the world's oceans. Acta Bot. Croat. 2005, 64, 129-212. 
24. Jacobson, D.M.; Anderson, R.A. The discovery of mixotrophy in photosynthetic species of Dinophysis (Dinophyceae): Light and electron microscopical observations of food vacuoles in Dinophysis acuminata, D. norvegica and two heterotrophic dinophysoid dinoflagellates. Phycologia 1994, 33, 97-110. [CrossRef]

25. Reguera, B.; Gil, S. Small cell and intermediate cell formation in species of Dinophysis (Dinophyceae, Dinophysiales). J. Phycol. 2001, 37, 318-333. [CrossRef]

26. Reguera, B.; Velo-Suárez, L.; Raine, R.; Park, M. Harmful Dinophysis species: A review. Harmful Algae 2012, 14, 87-106. [CrossRef]

27. Reguera, B.; Garcés, E.; Pazos, I.; Bravo, I.; Ramilo, I.; González-Gil, S. Cell cycle patterns and estimates of in situ division rates of dinoflagellates of the genus Dinophysis by a postmitotic index. Mar. Ecol. Prog. Ser. 2003, 249, 117-131. [CrossRef]

28. Reguera, B.; Pizarro, G. Planktonic Dinoflagellates Which Produce Polyether Toxins of the Old-DSP Complex. In Seafood and Freshwater Toxins: Pharmacology, Physiology and Detection, 2nd ed.; Botana, L.M., Ed.; Taylor \& Francis: London, UK, 2008; pp. 257-284.

29. Guzmán, L.; Campodonico, I. Marea roja en la región de Magallanes. Publ. Inst. Pat. Ser. Mon. 1975, 9, 44.

30. MacDonald, E. Dinophysis Bloom in West Scotland; Harmful Algae News Series No.9; Intergovernmental Oceanographic Commission of UNESCO: Paris, France, 1994.

31. Subba Rao, D.V.; Pan, Y.; Zitko, V.; Bugden, G.; Mackeigan, K. Diarrhetic shellfish poisoning (DSP) associated with a subsurface bloom of Dinophysis norvegica in Bedford Basin, eastern Canada. Mar. Ecol. Prog. Ser. 1993, 97, 117-126. [CrossRef]

32. Dahl, E.; Aune, T.; Aase, B. Reddish water due to mass occurrence of Dinophysis spp. In Harmful and Toxic Algal Blooms; Yasumoto, T., Oshima, Y., Fukuyo, Y., Eds.; Intergovernmental Oceanographic Commission of UNESCO: Paris, France, 1996; pp. 265-267.

33. Reguera, B.; Riobó, P.; Rodríguez, F.; Díaz, P.A.; Piazarro, G.; Paz, B.; Franco, J.M.; Blanco, J. Dinophysis toxins: Causative organisms, distribution and fate in shellfish. Mar. Drugs 2014, 12, 394-461. [CrossRef] [PubMed]

34. Santhanam, R.; Srinivasan, A. Impact of dinoflagellate Dinophysis caudata bloom on the hydrography and fishery potentials of Tuticorin Bay, South India. In Harmful and Toxic Algal Blooms; Yasumoto, Y., Oshima, Y., Fukuyo, Y., Eds.; IOC of UNESCO: Sendai, Japan, 1996; pp. 41-44.

35. Poletti, R.; Cettul, K.; Bovo, F.; Milandri, A.; Pompei, M.; Frate, R. Distribution of toxic dinoflagellates and their impact on shellfish along the northwest Adriatic coast. In Harmful Algae; Reguera, B., Blanco, J., Fernández, M.L., Wyatt, T., Eds.; Xunta de Galicia and Intergovernmental Oceanographic Commission of UNESCO: Santiago de Compostela, Spain, 1998; pp. 88-90.

36. Morton, S.T.; Vershinin, A.; Smith, L.L.; Leighfield, T.A.; Pankov, S.; Quilliam, M.A. Seasonality of Dinophysis spp. and Prorocentrum lima in Black Sea phytoplankton and associated shellfish toxicity. Harmful Algae 2009, 8, 629-639. [CrossRef]

37. Pizarro, G.; Moroño, A.; Paz, P.; Franco, J.M.; Pazos, Y.; Reguera, B. Evaluation of passive samplers as a monitoring tool for early warning of Dinophysis toxins in shellfish. Mar. Drugs 2013, 11, 3823-3845. [CrossRef] [PubMed]

38. Tahri-Joutei, L. Gymnodinium catenatum Graham blooms on Moroccan waters. In Harmful Algae; Reguera, B., Blanco, J., Fernández, M.L., Wyatt, T., Eds.; Xunta de Galicia and Intergovernmental Oceanographic Commission of UNESCO: Santiago de Compostela, Spain, 1998; pp. 66-67.

39. Flores, M.; Franco, J.M.; Lluch Cota, S.E.; Lluch Cota, D.B.; Cortés-Altamirano, R.; Sierra-Beltrán, A.P. Recent species shifts on the HAB occurrences in Acapulco Bay, Mexico. In Harmful Algae 2002, Proceedings of the 10th International Conference on Harmful Algae, St. Pete Beach, FL, USA, 21-25 October 2002; Steidinger, K.A., Landsberg, J.H., Tomas, C.R., Vargo, G.A., Eds.; Florida Fish and Wildlife Conservation Commission, Florida Institute of Oceanography and Intergovernmental Oceanographic Commission of UNESCO: Paris, France, 2002; p. 96.

40. Dickey, R.; Fryxell, G.; Granade, R.; Roelke, D. Detection of the marine toxins okadaic acid and domoic acid in shellfish and phytoplankton in the Gulf of Mexico. Toxicon 1992, 30, 355-359. [CrossRef]

41. Méndez, S.; Ferrari, G. Floraciones algales nocivas en Uruguay: Antecedentes, proyectos en curso y revisión de resultados. In Floraciones Algales Nocivas en el Cono Sur Americano; Sar, E.A., Ferrario, M.E., Reguera, B., Eds.; Instituto Español de Oceanografía: Madrid, Spain, 2002; pp. 271-288. (In Spanish) 
42. Sar, E.A.; Sunesen, I.; Lavigne, A.; Goya, A. Dinophysis spp. asociadas a detección de toxinas diarreicas (DSTs) en moluscos y a intoxicación diarreica en humanos (Provincia de Buenos Aires, Argentina). Rev. Biol. Mar. Oceanogr. 2010, 45, 451-460, (In Spanish). [CrossRef]

43. Fukuyo, Y.; Toyoda, Y.; Miyazaki, S. Dinoflagellates found in Sanriku Coast-I. Genus Dinophysis. Otsuchi Mar. Res. Cent. Rep. 1981, 7, 13-23.

44. Tseng, C.K.; Zhou, M.J.; Zou, J.Z. Toxic Phytoplankton Studies in China. In Toxic Phytoplankton Blooms in the Sea; Smayda, T.J., Shimizu, Y., Eds.; Elsevier: Amsterdam, The Netherlands, 1993; pp. 347-352.

45. Holmes, M.J.; Teo, S.L.M. Toxic marine dinoflagellates in Singapore waters that cause seafood poisonings. Clin. Exp. Pharmacol. Physiol. 2002, 29, 829-836. [CrossRef] [PubMed]

46. Karunasagar, I.; Segar, K.; Karunasagar, I. Incidence of PSP and DSP in shellfish along the coast of Karnataka State (India). In Red Tides. Biology, Enviromental Science and Toxicology; Okaichi, T., Anderson, D.M., Nemoto, T., Eds.; Elsevier: New York, NY, USA, 1989; pp. 61-64.

47. Burgess, V.; Shaw, G. Pectenotoxins-An issue for public health. A review of their comparative toxicology and metabolism. Environ. Int. 2001, 27, 275-283. [CrossRef]

48. Lee, J.S.; Tangen, K.; Dahl, E.; Hovgaard, P.; Yasumoto, T. Diarrhetic shellfish toxins in Norwegian mussels. Nippon Suisan Gakk. 1989, 54, 1953-1957. [CrossRef]

49. Marasigan, A.N.; Sato, S.; Fukuyo, Y.; Kodama, M. Accumulation of a high level of diarrhetic shellfish toxins in the green mussel Perna viridis during a bloom of Dinophysis caudata and Dinophysis miles in Saipan Bay, Panay Island, the Philippines. Fish. Sci. 2001, 67, 994-996. [CrossRef]

50. Fernández, M.L.; Reguera, B.; González-Gil, S.; Míguez, A. Pectenotoxin-2 in single-cell isolates of Dinophysis caudata and Dinophysis acuta from the Galician Rías (NW Spain). Toxicon 2006, 48, 477-490. [CrossRef] [PubMed]

51. Fernández, M.L.; Reguera, B.; Ramilo, I.; Martínez, A. Toxin content of Dinophysis acuminata, D. acuta and D. caudata from the Galician Rías Baixas. In Harmful Algal Blooms; Hallegraeff, G.M., Blackburn, S.I., Bolch, C.J., Lewis, R.J., Eds.; Intergovernmental Commission of UNESCO: Paris, France, 2001; pp. 360-363.

52. Okaichi, T. Red tides found in and around the Seto Inland Sea in 1965. Tech. Bull. Fac. Agric. Kagawa Univ. 1967, 18, 181-185.

53. Holmes, M.; Teo, S.; Lee, F.; Khoo, H. Persistent low concentrations of diarrhetic shellfish toxins in green mussels Perna viridis from the Johor Strait, Singapore: First record of diarrhetic shellfish toxins from South-East Asia. Mar. Ecol. Prog. Ser. 1999, 181, 257-268. [CrossRef]

54. Basti, L.; Uchida, H.; Kanamori, M.; Matsushima, R.; Suzuki, T.; Nagai, S. Mortality and pathology of Japanese scallop, Patinopecten (Mizuhopecten) yessoensis, and noble scallop, Mimachlamys nobilis, fed monoclonal culture of PTX-producer, Dinophysis caudata. In Marine and Freshwater Harmful Algae, Proceedings of the 16th International Conference on Harmful Algae, Wellington, New Zealand, 27-30 October 2014; MacKenzie, A.L., Ed.; Cawthron Institute, Nelson, New Zealand and International Society for the Study of Harmful Algae: Wellington, New Zealand, 2014; pp. 105-108.

55. Nishitani, G.; Nagai, S.; Sakiyama, S.; Kamiyama, T. Successful cultivation of the toxic dinoflagellate Dinophysis caudata (Dinophyceae). Plankton Benthos Res. 2008, 3, 78-85. [CrossRef]

56. Park, M.G.; Kim, S.; Kim, H.S.; Myung, G.; Kang, Y.G.; Yih, W. First successful culture of the marine dinoflagellate Dinophysis acuminata. Aquat. Microb. Ecol. 2006, 45, 101-106. [CrossRef]

57. Nagai, S.; Nitshitani, G.; Tomaru, Y.; Sakiyama, S.; Kamiyama, T. Predation by the toxic dinoflagellate Dinophysis fortii on the ciliate Myrionecta rubra and observation of sequestration of ciliate chloroplasts. J. Phycol. 2008, 44, 909-922. [CrossRef]

58. Nishitani, G.; Nagai, S.; Takano, Y.; Sakiyama, S.; Baba, K.; Kamiyama, T. Growth characteristics and phylogenetic analysis of the marine dinoflagellate Dinophysis infundibulus (Dinophyceae). Aquat. Microb. Ecol. 2008, 52, 209-221. [CrossRef]

59. Rodríguez, F.; Escalera, L.; Reguera, B.; Rial, P.; Riobó, P.; da Silva, T.J. Morphological variability, toxinology and genetics of the dinoflagellate Dinophysis tripos (Dinophysiaceae, Dinophysiales). Harmful Algae 2012, 13, 26-33. [CrossRef]

60. Nagai, S.; Suzuki, T.; Kamiyama, T. Successful cultivation of the toxic dinoflagellate Dinophysis tripos (Dinophyceae). Plankton Benthos Res. 2013, 8, 171-177. [CrossRef]

61. Jaén, D.; Mamán, L.; Domínguez, R.; Martín, E. First report of Dinophysis acuta in culture. Harmful Algal News 2009, 39, 1-2. 
62. Mafra, L.L., Jr. Detecção de Toxinas eEfeitos Tóxicos em Microalgas Cultivadas ou Coletadas na Costa sul do Brasil: Estado da Arte em 2013. In Livro de Resumos da Reunião Latino-Americana sobre Algas Nocivas, Santa Catarina, Brasil, 7-9 de Outubro, 2013; Proença, L.A.O., Renan de Souza, K., Eds.; Laboratory of Research and Monitoring of Harmful Algae and Phycotoxins: Santa Catarina, Brazil, 2013; p. 18. (In Portuguese)

63. Riobó, P.; Reguera, B.; Franco, J.M.; Rodríguez, F. First report of the toxin profile of Dinophysis sacculus Stein from LC-MS analysis of laboratory cultures. Toxicon 2013, 76, 221-224. [CrossRef] [PubMed]

64. Cembella, A.D.; John, U. Molecular physiology of toxin production and growth regulation in harmful algae. In Ecology of Harmful Algae; Graneli, E., Turner, J.T., Eds.; Springer-Verlag: Heidelberg, Germany, 2006; pp. 215-227.

65. Kamiyama, T.; Suzuki, T. Production of dinophysis-1 and pectenotoxin-2 by a culture of Dinophysis acuminata (Dinophyceae). Harmful Algae 2009, 8, 312-317. [CrossRef]

66. Nagai, S.; Suzuki, T.; Nishikawa, T.; Kamiyama, T. Differences in the production and excretion kinetics of okadaic acid, dinophysistoxin-1, and pectenotoxin-2 between cultures of Dinophysis acuminata and Dinophysis fortii isolated from western Japan. J. Phycol. 2011, 47, 1326-13337. [CrossRef]

67. Kamiyama, T.; Nagai, S.; Suzuki, T.; Miyamura, K. Effect of temperature on production of okadaic acid, dinophysistoxin-1, and pectenotoxin-2 by Dinophysis acuminata in culture experiments. Aquat. Microb. Ecol. 2010, 60, 193-202. [CrossRef]

68. Tong, M.; Kulis, D.M.; Fux, E.; Smith, J.L.; Hess, P.; Zhou, Q.; Anderson, D.M. The effects of growth phase and light intensity on toxin production by Dinophysis acuminata from northeastern United States. Harmful Algae 2011, 10, 254-264. [CrossRef]

69. Watton, P.S. Temperature and lake-outlet communities. J. Therm. Biol. 1995, 20, 121-125. [CrossRef]

70. Hansen, P.J.; Bjørnsen, P.K.; Hansen, B.W. Zooplankton grazing and growth: Scaling within the 2-2000- $\mu \mathrm{m}$ body size range. Limnol. Oceanogr. 1997, 42, 687-704. [CrossRef]

71. Crawford, D.W. Mesodinium rubrum: The phytoplankter that wasn't. Mar. Ecol. Prog. Ser. 1989, 58, 161-174. [CrossRef]

72. Fenchel, T.; Hansen, R.S. Motile behavior of the bloom-forming ciliate Mesodinium rubrum. Mar. Biol. Res. 2006, 2, 33-40. [CrossRef]

73. Yih, W.; Kim, H.S.; Jeong, H.J.; Myung, G.; Kim, Y.G. Ingestion of cryptophyte cells by the marine photosynthetic ciliate Mesodiunium rubrum. Aquat. Microb. Ecol. 2004, 36, 165-170. [CrossRef]

74. Jakobsen, H.H.; Everett, L.M.; Strom, S.L. Hydromechanical signaling between the ciliate Mesodinium pulex and motile prey. Mar. Ecol. Prog. Ser. 2006, 44, 197-206. [CrossRef]

75. Riisgård, H.U.; Larsen, P.S. Ciliary-propelling mechanism, effects of temperature and viscosity on swimming speed, and adaptive significance of "jumping" in the ciliate Mesodinium rubrum. Mar. Biol. Res. 2009, 5, 585-595. [CrossRef]

76. Reguera, B.; Bravo, I.; McCall, H.; Reyero, M.I. Phased cell division and other biological observations in field populations of Dinophysis spp. during cell cycle studies. In Harmful and Toxic Algal Blooms; Yasumoto, T., Fukuyo, Y., Eds.; IOC of UNESCO: Paris, France, 1996; pp. 257-260.

77. Sun, F.; Zhou, Q.X. Metal accumulation in the polychaete Hediste japonica with emphasis on interaction between heavy metals and petroleum hydrocarbons. Environ. Pollut. 2007, 149, 92-98. [CrossRef] [PubMed]

78. Riisgård, K.; Hansen, P.J. Role of food uptake for photosynthesis, growth and survival of the mixotrophic dinoflagellate Dinophysis acuminata. Mar. Ecol. Prog. Ser. 2009, 381, 51-62. [CrossRef]

79. Kim, S.; Kang, Y.G. Growth and grazing responses of the mixotrophic dinoflagellate Dinophysis acuminata as functions of light intensity and prey concentration. Aquat. Microb. Ecol. 2008, 51, 301-310. [CrossRef]

80. Chou, R.; Lee, H.B. Commercial marine fish farming in Singapore. Aquac. Res. 1997, 28, 767-776. [CrossRef]

81. Guillard, R.R.L. Culture of phytoplankton for feeding marine Invertebrates. In Culture of Marine Invertebrate Animals; Smith, W.L., Chanley, M.H., Eds.; Plenum Press: New York, USA, 1975; pp. 26-60.

82. Nagai, S.; Matsuyama, Y.; Oh, S.J.; Itakura, S. Effects of nutrients and temperate on encystement of the toxic dinoflagellate Alexandrium tamarense (Dinophyceae) isolated from Hiroshima Bay, Japan. Plankton Biol. Ecol. 2004, 51, 103-109.

83. Guillard, R.R.L. Division rates. In Handbook of Physiological Methods: Culture of Methods and Growth Measurements; Stein, J.R., Ed.; Cambridge University: Cambridge, UK, 1975; pp. 289-311.

84. Suzuki, T.; Mitsuya, T.; Imai, M.; Yamasaki, M. DSP toxin contents in Dinophysis fortii and scallops collected at Mutsu Bay, Japan. J. Appl. Phycol. 1997, 8, 509-515. [CrossRef] 
85. Suzuki, T.; Mitsuyama, T.; Matsubara, H.; Yamasaki, M. Determination of pectenotoxin-2 after solid-phase extraction from seawater and from the dinoflagellate Dinophysis fortii by liquid chromatography with electrospray mass spectrometry and ultraviolet detection: Evidence of oxidation of pectenotoxin-2 to pectenotoxin-6 in scallops. J. Chromatogr. A 1998, 815, 155-160. [PubMed]

86. Suzuki, T.; MacKenzie, L.; Stirling, D.; Adamson, J. Conversion of pectenotoxin-2 to pectenotoxin-2 seco acid in the New Zealand scallop, Pecten novaezelandiae. Fish. Sci. 2001, 67, 506-510. [CrossRef]

87. Anderson, D.M.; Kulis, D.M.; Sullivan, J.J.; Hall, S.; Lee, C. Dynamics and physiology of saxitoxin production by the dinoflagellate Alexandrium spp. Mar. Biol. 1990, 104, 511-524. [CrossRef]

88. Suzuki, T.; MacKenzie, L.; Stirling, D.; Adamson, J. Pectenotoxin-2 seco acid: A toxin converted from pectenotoxin-2 by the New Zealand Greenshell mussel, Perna canaliculus. Toxicon 2001, 39, 507-514. [CrossRef]

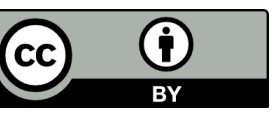

(C) 2015 by the authors; licensee MDPI, Basel, Switzerland. This article is an open access article distributed under the terms and conditions of the Creative Commons by Attribution (CC-BY) license (http://creativecommons.org/licenses/by/4.0/). 